\title{
Psychromonas hadalis sp. nov., a novel piezophilic bacterium isolated from the bottom of the Japan Trench
}

Correspondence

Yuichi Nogi

nogiy@jamstec.go.jp

\author{
Yuichi Nogi, Shoichi Hosoya, † Chiaki Kato and Koki Horikoshi
}

\author{
Extremobiosphere Research Center, Japan Agency for Marine-Earth Science and Technology \\ (JAMSTEC), 2-15 Natsushima-cho, Yokosuka 237-0061, Japan
}

Psychrophilic and piezophilic bacteria have been isolated from deep-sea environments. They are interesting because of their physiological adaptations, which enable them to survive at high pressure and low temperatures, and because they contribute to our understanding of the interactions between the deep-sea environment and its microbial inhabitants (Kato et al., 1995, 1998; Nogi et al., 1998, 2004; Yayanos et al., 1979). All piezophilic bacteria isolated to date fall into the class Gammaproteobacteria, according to phylogenetic classifications based on 16S rRNA gene sequence information (DeLong et al., 1997; Nogi \& Kato, 1999; Nogi et al., 2002). Margesin \& Nogi (2004) reported that 11 cultivated psychrophilic and piezophilic deep-sea species were affiliated with genera within the Gammaproteobacteria: Shewanella, Photobacterium, Colwellia, Moritella and Psychromonas. Members of the genus Psychromonas were isolated from the polar circles and deep-sea environments. Most of these isolates are not piezophilic strains. Psychromonas kaikoae $\mathrm{JT} 7304^{\mathrm{T}}$ (Nogi et al., 2002) and Psychromonas profunda $2825^{\mathrm{T}}$ (Xu et al., 2003) were reported to be piezophilic strains within this group. In this study, a novel obligately piezophilic, $\mathrm{C}_{22: 6}$ (docosahexaenoic acid)-producing bacterium of the genus Psychromonas is proposed on the basis of polyphasic studies.

†Present address: Laboratory of Bioresources, Institute of Molecular and Cellular Biosciences, The University of Tokyo, 1-1-1 Yayoi, Bunkyoku, Tokyo 113-0032, Japan.

The GenBank/EMBL/DDBJ accession number for the $16 \mathrm{~S}$ rRNA gene sequence of strain $\mathrm{K} 41 \mathrm{G}^{\top}$ is $\mathrm{AB} 094413$.
Strain $\mathrm{K}_{41 \mathrm{G}^{\mathrm{T}}}$ was isolated from deep-sea sediment samples collected in November 2000 using sterilized mud samplers on the unmanned submersible KAIKO in the Japan Trench $\left(38^{\circ}\right.$ $0.5^{\prime} \mathrm{N} 143^{\circ} 59.9^{\prime} \mathrm{E}$ ), at a depth of $7542 \mathrm{~m}$. This piezophilic strain was maintained on marine agar 2216 (Difco) and was grown at $6{ }^{\circ} \mathrm{C}$ and $60 \mathrm{MPa}$. High-pressure cultivation was achieved using a liquid hydraulic system. Piezophilic bacteria were cultivated in a plastic bag containing liquid medium in a pressure vessel made of stainless steel (SUS304). If necessary, oxygen-saturated fluorinert (FC-72; Sumitomo-3M) was added to supply oxygen to the cultures $(20 \%$ of total volume). This was performed according to the procedure reported previously (Kato et al., 1994; Yanagibayashi et al., 1999). Optimal pressure and temperature for growth were measured by monitoring the optical density. These tests were performed anaerobically in marine broth 2216 under various pressure and temperature conditions.

Cells of the isolated deep-sea strain $\mathrm{K}_{41 \mathrm{G}^{\mathrm{T}}}$ were found to be Gram-negative rods, $1.5-2 \mu \mathrm{m}$ long and $0.8-1.0 \mu \mathrm{m}$ wide, and motile by means of a single unsheathed polar flagellum. The strain was unable to grow at atmospheric pressure at $2-15^{\circ} \mathrm{C}$, although it grew well in pressure vessels under hydrostatic pressures of 30-90 MPa at $6^{\circ} \mathrm{C}$ and $60-90 \mathrm{MPa}$ at $10^{\circ} \mathrm{C}$. No growth occurred at $15^{\circ} \mathrm{C}$ under the pressures examined. The most rapid growth rate (about $0.14 \mathrm{~h}^{-1}$ ) was observed at $60 \mathrm{MPa}$ and $6^{\circ} \mathrm{C}$ (Fig. 1).

Physiological tests were performed under high-pressure conditions to determine acid production from sugars and 


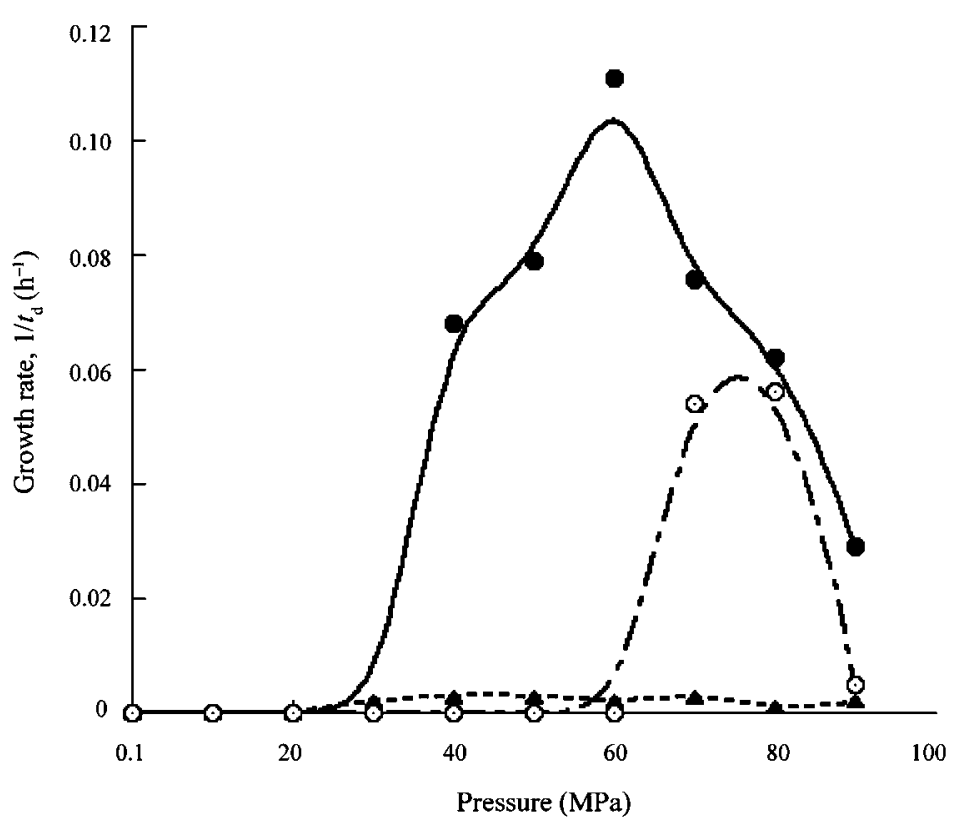

Fig. 1. Pressure-dependent growth rate of strain $\mathrm{K} 41 \mathrm{G}^{\top}$ at $2{ }^{\circ} \mathrm{C}(\boldsymbol{A}), 6^{\circ} \mathrm{C}(\mathbf{O})$ and $10^{\circ} \mathrm{C}$ $(\odot)$. Growth rates were determined based on optical density. $t_{\mathrm{d}}$, Doubling time (h). fermentation test cultures were grown using modified OF medium (Nogi et al., 2002) to examine hydrogen sulfide production from thiosulfate, production of indole, fermentation and oxidization, gelatinase activity and oxidase and catalase production, according to methods described previously (Nogi \& Kato, 1999; Nogi et al., 2002).

The characteristics of strain $\mathrm{K} 41 \mathrm{G}^{\mathrm{T}}$ and reference strains are shown in Table 1 . Strain $\mathrm{K}_{4} 1 \mathrm{G}^{\mathrm{T}}$ was a facultatively anaerobic, chemo-organotroph, displaying both respiratory and fermentative types of metabolism. Strain $\mathrm{K}_{41 \mathrm{G}}^{\mathrm{T}}$ shared many physiological characteristics with members of the genus Psychromonas. However, unlike the reference strains of Psychromonas, strain $\mathrm{K}_{4} 1 \mathrm{G}^{\mathrm{T}}$ did not utilize cellobiose or sucrose and reduced nitrite, and strain $\mathrm{K}_{41 \mathrm{G}^{\mathrm{T}}}$ and Psychromonas kaikoae were unable to grow at atmospheric pressure.

To determine the phylogenetic relationships, 16S rRNA gene sequences were obtained by direct sequencing of PCRamplified DNA, as described previously (Kato et al., 1998). Nucleotide substitution rates ( $K_{\text {nuc }}$; Kimura, 1980) were determined and a distance matrix tree was constructed using the neighbour-joining method (Saitou \& Nei, 1987) with the program CLUSTAL_X (Thompson et al., 1997). Alignment gaps and unidentified base positions were not taken into consideration in the calculations. The topology of the phylogenetic tree was evaluated by performing bootstrap analysis with 1000 bootstrapped trials. The results of phylogenetic analyses based on 16S rRNA gene sequence information support the conclusions described below and further clarify the taxonomic and phylogenetic position of the novel isolate among members of the genus Psychromonas and related genera. The results of the phylogenetic analyses are shown in Fig. 2. Strain $\mathrm{K} 41 \mathrm{G}^{\mathrm{T}}$ falls into the genus Psychromonas and is closely related to the psychrotrophic species Psychromonas arctica (96.1\%) and the piezophilic species Psychromonas profunda (97.0\%). The generally recommended and accepted criteria for delineating bacterial species state that strains with $16 \mathrm{~S}$ rRNA gene sequence dissimilarity greater than $3 \%$ are considered to belong to separate species (Stackebrandt \& Goebel, 1994; Stackebrandt et al., 2002). For analysis of relatedness, DNA-DNA hybridization was carried out at $40{ }^{\circ} \mathrm{C}$ for $3 \mathrm{~h}$ and was measured fluorometrically using the method of Ezaki et al. (1989). The DNA-DNA hybridization value between strain $\mathrm{K}_{41 \mathrm{G}^{\mathrm{T}}}$ and the reference strain Psychromonas profunda was less than $40 \%$. This level of relatedness is significantly lower than that accepted as the phylogenetic definition of a species (Wayne et al., 1987). This and other results in Table 1 and Fig. 2 suggest that strain $K 41 G^{T}$ represents a novel Psychromonas species.

The whole-cell fatty acid compositions of the piezophilic strain $\mathrm{K} 41 \mathrm{G}^{\mathrm{T}}$ and reference strains are shown in Table 2. The major fatty acids of strain $\mathrm{K}_{41 \mathrm{G}^{\mathrm{T}}}$ were $\mathrm{C}_{14: 1}$ (tetradecenoic acid), $\mathrm{C}_{16: 0}$ (hexadecanoic acid), $\mathrm{C}_{16: 1}$ (hexadecenoic acid) and $\mathrm{C}_{22: 6}$. There was a low level of similarity between this fatty acid profile and those of the reference strains. For example, the predominant components in the fatty acid profiles of the reference strains differed from those in the profile of strain $\mathrm{K} 41 \mathrm{G}^{\mathrm{T}}$, which contained substantial amounts of $\mathrm{C}_{14: 1}$ and $\mathrm{C}_{22: 6}$ and does not have the long-chain unsaturated fatty acid $\mathrm{C}_{18: 1}$ (octadecenoic acid).

On the basis of the phenotypic, genotypic and phylogenetic data, we conclude that the isolate is a member of the genus Psychromonas and that it represents a novel species within this genus, for which the name Psychromonas hadalis sp. nov. is proposed. 
Table 1. Phenotypic characteristics of strain $\mathrm{K}_{4} 1 \mathrm{G}^{\top}$ and other members of the genus Psychromonas

Strains: 1, strain $\mathrm{K}_{41 \mathrm{G}^{\mathrm{T}}}$ (Psychromonas hadalis sp. nov.); 2, Psychromonas antarctica DSM 10704 ; 3, Psychromonas arctica Pull 5.3 ; 4, Psychromonas ingrahamii $37^{\mathrm{T}} ; 5$, Psychromonas kaikoae JT7304 ${ }^{\mathrm{T}} ; 6$, Psychromonas marina 4-22 $2^{\mathrm{T}} ; 7$, Psychromonas profunda $2825^{\mathrm{T}}$. All strains were Gram-negative, oxidase-positive and catalase-positive, and were able to use D-fructose, D-glucose, maltose and D-mannitol. Data for reference species are from Mountfort et al. (1998), Groudieva et al. (2003), Auman et al. (2006), Nogi et al. (2002), Kawasaki et al. (2002) and $\mathrm{Xu}$ et al. (2003). +, Positive; -, negative; ND, no data available.

\begin{tabular}{|c|c|c|c|c|c|c|c|}
\hline Characteristic & 1 & 2 & 3 & 4 & 5 & 6 & 7 \\
\hline \multicolumn{8}{|l|}{ Growth temperature $\left({ }^{\circ} \mathrm{C}\right)$ : } \\
\hline Range & $2-12$ & $2-17$ & $0-25$ & -12 to 10 & $4-15$ & $0-25$ & $2-14$ \\
\hline Optimum & 6 & 12 & 20 & 5 & 10 & $14-16$ & 10 \\
\hline Optimum pressure (MPa) & 60 & $0.1-10$ & ND & ND & 50 & 0.1 & 25 \\
\hline Growth at atmospheric pressure & - & + & + & + & - & + & + \\
\hline Motility & + & + & + & - & + & + & + \\
\hline DNA G $+C$ content $(\mathrm{mol} \%)$ & 39.1 & 43 & 40.1 & 40 & 43.8 & 43.5 & 38.1 \\
\hline Quinone & Q-8 & Q-8 & ND & $\mathrm{ND}$ & Q-8 & Q-8 & Q-8 \\
\hline Gelatinase & - & + & - & - & + & - & - \\
\hline Amylase & - & - & + & - & - & + & + \\
\hline Production of $\mathrm{H}_{2} \mathrm{~S}$ & - & - & ND & ND & - & + & + \\
\hline Production of indole & - & - & ND & - & - & - & + \\
\hline Reduction of nitrate & + & - & - & + & + & + & + \\
\hline Reduction of nitrite & + & - & ND & ND & - & ND & - \\
\hline Gas production from glucose & - & + & + & - & - & - & - \\
\hline \multicolumn{8}{|l|}{ Acid produced from: } \\
\hline L-Arabinose & - & - & ND & - & - & - & - \\
\hline Cellobiose & - & + & ND & + & + & + & + \\
\hline D-Galactose & + & + & $\mathrm{ND}$ & + & + & + & + \\
\hline Glycerol & + & - & + & + & + & + & + \\
\hline myo-Inositol & - & - & $\mathrm{ND}$ & - & - & - & + \\
\hline D-Lactose & - & - & + & + & - & + & + \\
\hline D-Mannose & + & - & + & - & + & - & + \\
\hline D-Raffinose & - & - & ND & $\mathrm{ND}$ & - & - & - \\
\hline L-Rhamnose & - & - & ND & ND & - & - & + \\
\hline D-Sorbitol & - & - & ND & - & - & - & - \\
\hline Sucrose & - & + & + & + & + & + & + \\
\hline D-Trehalose & + & + & ND & + & + & - & + \\
\hline Xylose & - & - & - & - & - & + & + \\
\hline
\end{tabular}

\section{Description of Psychromonas hadalis sp. nov.}

Psychromonas hadalis [ha.da'lis. N.L. fem. adj. hadalis (from Greek Haidess), hadal of or relating to the deepest regions of the ocean].
Cells are Gram-negative rods, $1.5-2 \mu \mathrm{m}$ long and $0.8-1.0 \mu \mathrm{m}$ wide, and motile by means of a single unsheathed polar flagellum. Halophilic, psychrophilic and piezophilic. Optimal growth occurs at a $\mathrm{NaCl}$ concentration of about $3 \%$. No growth occurs in the absence of $\mathrm{NaCl}$.

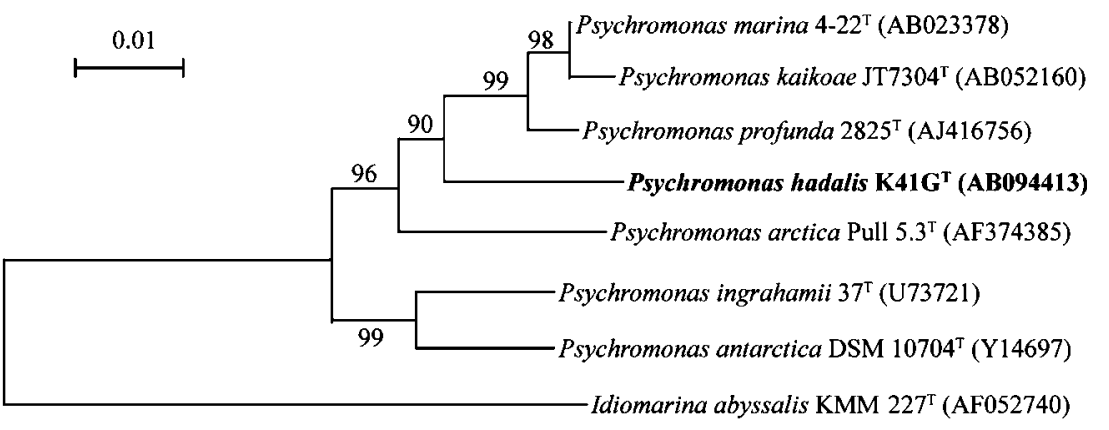

Fig. 2. Phylogenetic tree constructed using the neighbour-joining method and based on 16S rRNA gene sequences showing the relationships of strain $\mathrm{K}_{4} 1 \mathrm{G}^{\top}$ within the genus Psychromonas. Percentage bootstrap values were calculated from multiple resamplings of the sequence dataset. Bar, 0.01 (mean) nucleotide substitutions per site. 
Table 2. Whole-cell fatty acid content of strain $\mathrm{K}_{4} 1 \mathrm{G}^{\top}$ (Psychromonas hadalis sp. nov.) and other members of the genus Psychromonas

Strains: 1, strain $\mathrm{K}_{41 \mathrm{G}^{\mathrm{T}}}$ (Psychromonas hadalis sp. nov.); 2, Psychromonas antarctica DSM 10704 ${ }^{\mathrm{T}}$; 3, Psychromonas arctica Pull 5.3 ${ }^{\mathrm{T}}$; 4, Psychromonas ingrahamii $37^{\mathrm{T}} ; 5$, Psychromonas kaikoae JT7304 ${ }^{\mathrm{T}} ; 6$, Psychromonas marina 4-22 $2^{\mathrm{T}} ; 7$, Psychromonas profunda $2825^{\mathrm{T}}$. Values are percentages of total fatty acids. Values below $1 \%$ are not shown. Data are from this study, Nogi et al. (2002), Groudieva et al. (2003), Auman et al. (2006), Kawasaki et al. (2002) and $\mathrm{Xu}$ et al. (2003).

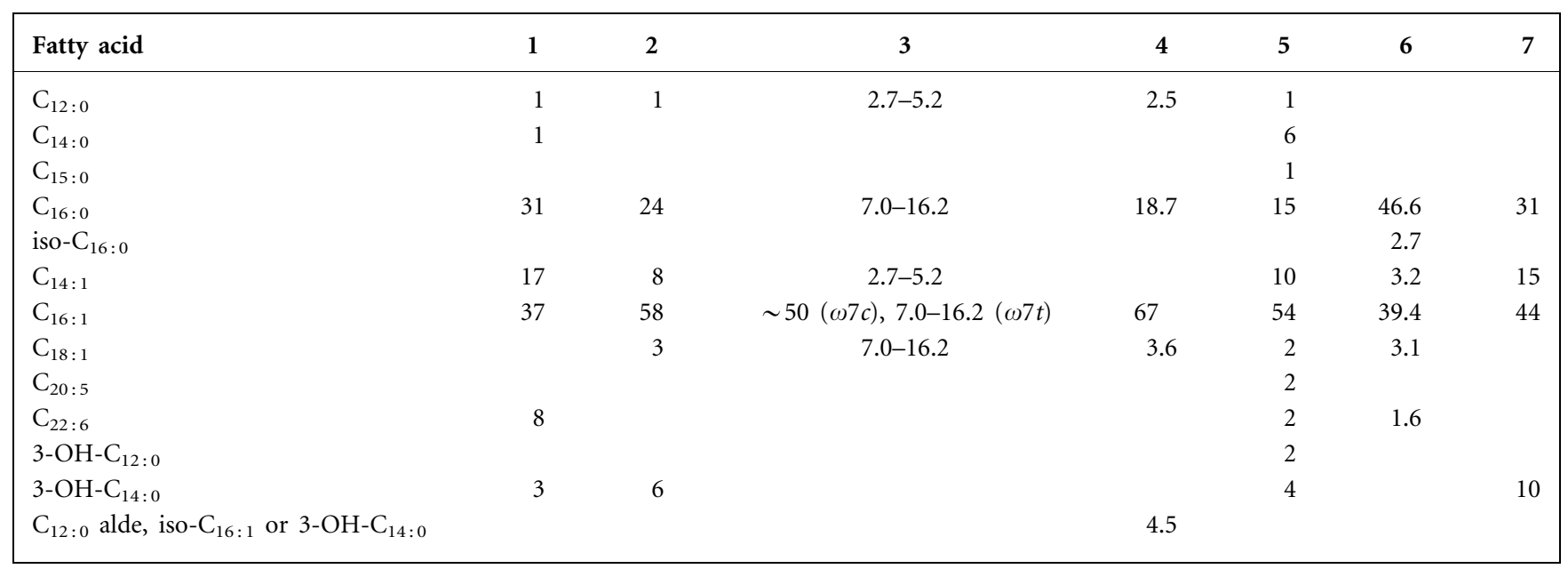

Optimal temperature and pressure for growth are $6{ }^{\circ} \mathrm{C}$ and $60 \mathrm{MPa}$, respectively. No growth occurs at atmospheric pressure. Facultatively anaerobic, chemo-organotroph, having both respiratory and fermentative types of metabolism. Catalase- and cytochrome oxidase-positive, nitrate is reduced to nitrite and nitrite is reduced to nitrogen. Gelatin is not hydrolysed, and amylase, $\mathrm{H}_{2} \mathrm{~S}$ production and indole production are negative. The DNA G $+\mathrm{C}$ content of the type strain is $39.1 \mathrm{~mol} \%$. The major isoprenoid quinone is Q-8. Predominant cellular fatty acids are $\mathrm{C}_{14: 1}, \mathrm{C}_{16: 0}, \mathrm{C}_{16: 1}$ and $\mathrm{C}_{22: 6}$. Other characteristics are shown in Table 1 .

The type strain is strain $\mathrm{K}_{41 \mathrm{G}^{\mathrm{T}}}\left(=\mathrm{JCM} 11830^{\mathrm{T}}=\mathrm{ATCC}\right.$ BAA- $638^{\mathrm{T}}$ ), which was isolated from sediment collected from the bottom of the Japan Trench.

\section{Acknowledgements}

We are very grateful to the KAIKO operation team and the crew of M.S. KAIREI for their help in collecting the deep-sea samples.

\section{References}

Auman, A. J., Breezee, J. L., Gosink, J. J., Kämpfer, P. \& Staley, J. T. (2006). Psychromonas ingrahamii sp. nov., a novel gas vacuolate, psychrophilic bacterium isolated from Arctic polar sea ice. Int J Syst Evol Microbiol 56, 1001-1007.

DeLong, E. F., Franks, D. G. \& Yayanos, A. A. (1997). Evolutionary relationships of cultivated psychrophilic and barophilic deep-sea bacteria. Appl Environ Microbiol 63, 2105-2108.

Ezaki, T., Hashimoto, Y. \& Yabuuchi, E. (1989). Fluorometric deoxyribonucleic acid-deoxyribonucleic acid hybridization in microdilution wells as an alternative to membrane filter hybridization in which radioisotopes are used to determine genetic relatedness among bacterial strains. Int J Syst Bacteriol 39, 224-229.
Groudieva, T., Grote, R. \& Antranikian, G. (2003). Psychromonas arctica sp. nov., a novel psychrotolerant, biofilm-forming bacterium isolated from Spitzbergen. Int J Syst Evol Microbiol 53, 539-545.

Kato, C., Sato, T., Smorawinska, M. \& Horikoshi, K. (1994). High pressure conditions stimulate expression of chloramphenicol acetyltransferase regulated by the lac promoter in Escherichia coli. FEMS Microbiol Lett 122, 91-96.

Kato, C., Sato, T. \& Horikoshi, K. (1995). Isolation and properties of barophilic and barotolerant bacteria from deep-sea mud samples. Biodivers Conserv 4, 1-9.

Kato, C., Li, L., Nogi, Y., Nakamura, Y., Tamaoka, J. \& Horikoshi, K. (1998). Extremely barophilic bacteria isolated from the Mariana Trench, Challenger Deep, at a depth of 11,000 meters. Appl Environ Microbiol 64, 1510-1513.

Kawasaki, K., Nogi, Y., Hishinuma, M., Nodasaka, Y., Matsuyama, H. \& Yumoto, I. (2002). Psychromonas marina sp. nov., a novel halophilic, facultatively psychrophilic bacterium isolated from the coast of the Okhotsk Sea. Int J Syst Evol Microbiol 52, 1455-1459.

Kimura, M. (1980). A simple method for estimating evolutionary rates of base substitutions through comparative studies of nucleotide sequences. J Mol Evol 16, 111-120.

Margesin, R. \& Nogi, Y. (2004). Psychropiezophilic microorganisms. Cell Mol Biol 50, 429-436.

Mountfort, D. O., Rainey, F. A., Burghardt, J., Kasper, F. \& Stackebrandt, E. (1998). Psychromonas antarcticus gen. nov., sp. nov., a new aerotolerant anaerobic, halophilic psychrophile isolated from pond sediment of the McMurdo Ice Shelf, Antarctica. Arch Microbiol 169, 231-238.

Nogi, Y. \& Kato, C. (1999). Taxonomic studies of extremely barophilic bacteria isolated from the Mariana Trench and description of Moritella yayanosii sp. nov., a new barophilic bacterial isolate. Extremophiles 3, 71-77.

Nogi, Y., Kato, C. \& Horikoshi, K. (1998). Taxonomic studies of deep-sea barophilic Shewanella strains and description of Shewanella violacea sp. nov. Arch Microbiol 170, 331-338. 
Nogi, Y., Kato, C. \& Horikoshi, K. (2002). Psychromonas kaikoae sp. nov., a novel piezophilic bacterium from the deepest cold-seep sediments in the Japan Trench. Int J Syst Evol Microbiol 52, 1527-1532.

Nogi, Y., Hosoya, S., Kato, C. \& Horikoshi, K. (2004). Colwellia piezophila sp. nov., a novel piezophilic species from deep-sea sediments of the Japan Trench. Int J Syst Evol Microbiol 54, 1627-1631.

Saitou, N. \& Nei, M. (1987). The neighbor-joining method: a new method for reconstructing phylogenetic trees. Mol Biol Evol 4, 406-425.

Stackebrandt, E. \& Goebel, B. M. (1994). Taxonomic note: a place for DNA-DNA reassociation and $16 \mathrm{~S}$ rRNA sequence analysis in the present species definition in bacteriology. Int J Syst Bacteriol 44, 846-849.

Stackebrandt, E., Frederiksen, W., Garrity, G. M., Grimont, P. A. D., Kämpfer, P., Maiden, M. C. J., Nesme, X., Rosselló-Mora, R., Swings, J. \& other authors (2002). Report of the ad hoc committee for the re-evaluation of the species definition in bacteriology. Int J Syst Evol Microbiol 52, 1043-1047.

Thompson, J. D., Gibson, T. J., Plewniak, F., Jeanmougin, F. \& Higgins, D. G. (1997). The CLUSTAL_X Windows interface: flexible strategies for multiple sequence alignment aided by quality analysis tools. Nucleic Acids Res 25, 4876-4882.

Wayne, L. G., Brenner, D. J., Colwell, R. R., Grimont, P. A. D., Kandler, O., Krichevsky, M. I., Moore, L. H., Moore, W. E. C., Murray, R. G. E. \& other authors (1987). International Committee on Systematic Bacteriology. Report of the ad hoc committee on reconciliation of approaches to bacterial systematics. Int J Syst Bacteriol 37, 463-464.

Xu, Y., Nogi, Y., Kato, C., Liang, Z., Rüger, H.-J., Kegel, D. D. \& Glansdorff, N. (2003). Psychromonas profunda sp. nov., a psychropiezophilic bacterium from deep Atlantic sediments. Int J Syst Evol Microbiol 53, 527-532.

Yanagibayashi, M., Nogi, Y., Li, L. \& Kato, C. (1999). Changes in the microbial community in Japan Trench sediment from a depth of 6,292 $\mathrm{m}$ during cultivation without decompression. FEMS Microbiol Lett 170, 271-279.

Yayanos, A. A., Dietz, A. S. \& Van Boxtel, R. (1979). Isolation of a deep-sea barophilic bacterium and some of its growth characteristics. Science 205, 808-810. 